\title{
Formulasi dan Evaluasi Krim Tabir Surya Ekstrak Daging Labu Kuning (Cucurbita maxima)
}

\author{
Agitya Resti Erwiyani*, Ayu Sonia Cahyani, Luluk Mursyidah, \\ Istianatus Sunnah, Anasthasia Pujistuti
}

Prodi Farmasi, Fakultas Kesehatan, Universitas Ngudi Waluyo

Jl. Diponegoro no 186 Gedanganak, Ungaran Timur, Kab. Semarang, Jawa Tengah, Indonesia ${ }^{*}$ Email : agityaresti@gmail.com

Submit 03/10/2021, Revisi 20/10/2021, Diterima 25/11/2021, Terbit 10/12/2021)

\begin{abstract}
Abstrak
Paparan sinar UV secara berlebih dapat menyebabkan imunosupresan, photoaging dan kanker kulit, apabila paparan mengenai lapisan kulit dermis akan menyebabkan kulit menjadi gelap, eritema serta terjadi kerusakan jaringan kolagen. Tabir surya memiliki mekanisme perlindungan secara fisik melalui penghamburan sinar matahari yang masuk ke dalam kulit serta perlindungan mekanik melalui absorbsi sinar UV. Senyawa alami yang berpotensi untuk dikembangkan sebagai kosmetik tabir surya melalui mekanisme antiaging adalah senyawa yang mempunya cincin aromatik seperti gugus fenol. Kandungan labu diketahui memiliki aktivitas antioksidan diantaranya polifenol, karotenoid dan tokoferol. Penelitian ini bertujuan untuk memformulasi krim daging buah labu kuning potensinya sebagai tabir surya melalui pengujian nilai SPF menggunakan metode Spektrofotometri. Evaluasi sediaan krim menunjukkan organoleptis berwarna kuning, berbau manis dan berbentuk semi padat. Krim daging labu kuning memiliki nilai $\mathrm{pH}$ yang berkisar antara $\quad 5,32-6,11$, daya sebar $5,04-5,31 \mathrm{~cm}$, daya lekat 2,77 - 3,73 detik, viskositas 4480 - $7360 \mathrm{cP}$, dan uji sentrifugasi krim tidak mengalami perubahan. Penyimpanan selama 14 hari sediaan stabil dan tidak mengalami perubahan yang signifikan berdasarkan paired sample $T$ test. Hasil pengujian aktivitas tabir surya menunjukkan nilai SPF F1, F2 dan F3 berturut - turut sebesar 2,15 $\pm 0,01$, $4,69 \pm 0,04$ dan 5,78 $\pm 0,02$. Krim dengan konsentrasi ekstrak daging buah labu kuning sebesar $5 \%$ dan $10 \%$ memiliki proteksi tabir surya kategori sedang.
\end{abstract}

Kata kunci: daging labu kuning, krim, tabir surya, SPF

\section{Pendahuluan}

Paparan sinar ultraviolet (UV) dikategorikan berdasarkan panjang gelombang sinar UV antara lain sinar UV C (100 - $290 \mathrm{~nm})$, sinar UV B $(290-320 \mathrm{~nm})$ dan sinar UV A (320 - $400 \mathrm{~nm}$ ). Paparan sinar UV tidak semuanya mencapai bumi, sinar UV yang dapat mencapai bumi diantaranya sinar UV A sebesar 90 - 99\% dan sinar UV B sebesar 1 $10 \%$ sedangkan sinar UV C diabsorbsi oleh lapisan ozon sehingga tidak sampai ke permukaan bumi (1). 
Paparan sinar UV yang cukup dapat memberikan manfaat pada tubuh diantaranya menstimulasi produksi vitamin D sedangkan paparan berlebih dapat memberikan dampak negatif bagi tubuh tergantung dari pigmentasi kulit, penggunaan tabir surya, waktu paparan sinar, musim, kelembaban serta polusi udara (2). Paparan sinar UV secara berlebih dapat menyebabkan imunosupresan, photoaging serta kanker kulit. Paparan UV yang masuk ke lapisan kulit dermis akan menyebabkan kulit menjadi gelap, eritema serta terjadi kerusakan jaringan kolagen akibat perubahan regulasi pada matriks metalloproteinase (MMP) yang disebabkan oleh reactive oxidative species (ROS) akibat sinar UV (2-4).

Salah satu langkah perlindungan paparan radiasi sinar UV dengan menggunakan tabir surya. Tabir surya bekerja dengan mengabsorpsi dan menghamburkan radiasi sinar UV A dan UV B sehingga dapat mencegah sunburn dan penuaan dini pada kulit. Tabir surya memiliki mekanisme perlindungan secara fisik melalui penghamburan sinar matahari yang masuk ke dalam kulit serta perlindungan mekanik melalui absorbsi sinar UV $(2,5)$. Beberapa penelitian menunjukkan penggunaan tabir surya seraca rutin mampu menurunkan potensi angka kejadian kanker kulit seperti melanoma dan squamous cell carcinoma (4). Tabir surya seringkali ditambahkan senyawa antioksidan alami yang berfungsi dapat menangkal radikal bebas sinar matahari tetapi keberadaan tabir surya alami selama ini masih terbatas dan belum dapat menggantikan tabir surya sintetik (2).

Tabir surya sintetik memiliki efek yang baik terhadap pelindungan terhadap sinar matahari namun penggunaannya terbatas karena dapat menyebabkan toksisitas pada manusia serta dapat menganggu jalur tertentu dari proses tahap karsinogenesis (1). Penggunaan tabir surya alami lebih menguntungkan karena toleran terhadap kulit manusia, aman serta memiliki tingkat iritasi yang rendah (6). Senyawa alami yang berpotensi untuk dikembangkan sebagai kosmetik tabir surya melalui mekanisme antiaging adalah senyawa yang mempunya cincin aromatik seperti gugus fenol $(1,7)$.

Labu kuning (Cucurbita maxima D.) merupakan tanaman yang tergolong ke dalam genus Cucurbita famili Cucurbitaceae. Labu kuning secara luas dimanfaatkan sebagai sayuran dan juga obat. Bagian tanaman baik daging hingga bijinya diolah menjadi makanan yang memiliki nilai gizi yang tinggi. Kandungan fitokimia labu kuning beragam diantaranya flavonoid, polifenol, saponin, potein dan karbohidrat. Labu kuning juga mengandung sumber nutrisi yang baik seperti vitamin A, zat besi, fosfor, dan kalsium. Kandungan labu yang bertanggung jawab pada aktivitas antioksidan adalah karotenoid dan tokoferol. $\beta$-karoten dapat menurunkan kerusakan kulit akibat paparan sinar matahari, agen inflamasi, meningkatkan fungsi imun serta menurunkan resiko penyakit seperti penyakit jantung dan kanker. $\alpha$-karoten dapat memperlambat proses penuaan, menurunkan resiko katarak dan mencegah pertumbuhan tumor. 
Vitamin $\mathrm{E}$ (tokoferol) dapat melindungi sel dari kerusakan dengan mencegah oksidasi asam lemak tak jenuh dalam membran sel $(8,9)$.

Daging buah labu kuning perlu dikembangkan pemanfaatannya sebagai kosmetik tabir surya dalam bentuk sediaan krim. Krim merupakan bentuk sediaan yang banyak diminati oleh konsumen wanita karena mudah digunakan, mudah tercuci dengan air serta memberikan efek melembabkan. Krim dapat menutupi permukaan kulit dengan cepat dan mampu memberikan perlindungan terhadap sinar matahari (7). Penelitian ini bertujuan untuk memformulasi krim daging buah labu kuning potensinya sebagai tabir surya melalui pengujian nilai SPF menggunakan metode Spektrofotometri.

\section{Metode}

\section{Alat}

Blender (Philips), alat gelas (Pyrex), neraca analitis (Ohauss), kain flannel, rotary evaporator (Biobase), panci stainless steel, pipet tetes, oven (Memmert), Lemari es (Sanken), Moisture Ballance, $\mathrm{pH}$ meter, $\mathrm{pH}$ meter (Ohaus Starter 300), waterbath (DHH-88), viscometer brookfield DV2T, alat uji daya sebar, alat uji daya lekat.

\section{Bahan}

Bahan utama yang digunakan adalah daging buah labu kuning (diperoleh dari Desa Getasan, Kabupaten Semarang), cera alba (MKR Chemicals), vaselin album (MKR Chemicals), VCO (PT.Belton Adi Pratma), akuades, propilen glikol (The Dow Chemical Company, Thailand), asam stearate (MKR Chemicals), TEA (MKR Chemicals).

Bahan kimia lain yang digunakan terdiri dari etanol 95\% (Bratachem), natrium klorida (Merck), kloroform (Merck), amonia (Merck), amil alkohol (Merck), eter (Merck), asam klorida (Merck), asam sulfat (Merck), pereaksi Mayer (Bratachem), pereaksi Dragendorff (Bratachem), pereaksi Liebermann-Burchard (Bratachem), serbuk magnesium (Bratachem), kalium hidroksida (Merck), larutan standar Mc Farland 0,5, besi (III) klorida (Merck), gelatin (Bratachem), vanilin (Bratachem), dimetil sulfoksida/DMSO (Merck), natrium viscolam AT 100P (Nardev), propilenglikol (Bratachem), metil paraben (Bratachem), propil paraben (Bratachem) dan air suling.

\section{Prosedur Rinci}

1. Preparasi Ekstrak Labu Kuning (Cucurbita maxima D.)

Buah labu kuning yang akan digunakan diperoleh dari Desa Getasan, Kabupaten Semarang. Preparasi ekstrak mengacu pada penelitian sebelumnya (10) dengan menyiapkan daging buah labu kuning, dikupas dan dipisahkan daging buah dan bijinya, selanjutnya dicuci sampai bersih, dipotong kecil dan tipis, lalu dikeringkan dengan cara diangin-anginkan terlebih dahulu. Daging buah labu kuning dilakukan pengeringan dengan diangin - anginkan pada sinar matahari tidak langsung dilanjutkan pengeringan oven pada suhu $50^{\circ} \mathrm{C}$. Serbuk simplisia diekstraksi menggunakan cara maserasi dengan pelarut etanol $96 \%$ selama jam. 
Ekstrak cair etanol yang diperoleh dipekatkan dengan rotary evaporator. Ekstrak kental buah labu kuning yang telah kental dilakukan perhitungan rendemen.

2. Formulasi Krim Ekstrak Daging Buah Labu Kuning (Cucurbita maxima D.)

Formulasi krim ekstrak daging buah labu kuning dibuat dengan variasi ekstrak dengan konsentrasi $5 \%, 10 \%$ dan $15 \% \mathrm{~b} / \mathrm{v}$. Formulasi basis merupakan sediaan krim sebagai formula basis tanpa ekstrak sedangkan formulasi F1, F2 dan F3 merupakan formula krim yang mengandung ekstrak daging buah labu kuning.

Tabel 1. Formulasi Krim Ekstrak Daging Buah Labu Kuning (Cucurbita maxima D.)

\begin{tabular}{cccccc}
\hline Nama Bahan & Fungsi Bahan (11) & \multicolumn{3}{c}{ Formula } \\
\cline { 3 - 6 } & & Basis & F1(\%) & F2(\%) & F3(\%) \\
\hline Ekstrak & Zat aktif & - & 5 & 10 & 15 \\
Asam stearate & Pengemulsi & 12 & 12 & 12 & 12 \\
Cera alba & Pengemulsi & 0,5 & 0,5 & 0,5 & 0,5 \\
Vaselin album & Basis & 10 & 10 & 10 & 10 \\
VCO & Fase minyak & 10 & 10 & 10 & 10 \\
Span 80 & Pengemulsi & 0,8 & 0,8 & 0,8 & 0,8 \\
Tween 80 & Pengemulsi & 4,2 & 4,2 & 3,2 & 3,2 \\
Propilen glikol & Humektan & 15 & 15 & 15 & 15 \\
Trietanolamin & Pengemulsi dan pengalkali & 3 & 3 & 3 & 3 \\
Akuades & Pelarut & 44,5 & 39,5 & 35,5 & 30,5 \\
\hline
\end{tabular}

3. Pembuatan krim dibuat dengan mencampurkan fase minyak (cera alba, vaselin album, asam stearate, paraffin cair, span 80 dan VCO) dengan metode pel eburan pada suhu $70^{\circ} \mathrm{C}$ hingga berubah bentuk menjadi cair dan aduk hingga homogen. Fase air dibuat dengan mencampurkan propilen glikol, tween 80, trietanolamin dan akuades, dicampurkan dalam beaker gelas dan dipanaskan pada suhu $\pm 5^{\circ} \mathrm{C}$ lebih tinggi dibandingkan fase minyak. Fase air dicampurkan dengan fase minyak sedikit demi sedikit dalam mortar panas dan setelah homogen dan suhu agak dingin dimasukkan ekstrak. sediaan basis tidak mengandung ekstrak sedangkan sediaan F1, F2 dan F3 mengandung ekstrak dengan variasi konsentrasi (12).

4. Evaluasi Stabilitas Sediaan Krim Ekstrak Daging Buah Labu Kuning

Pengamatan dilakukan pada setiap minggu pada penyimpanan suhu kamar meliputi organoleptis meliputi warna, tekstur dan bau, homogenitas, pengukuran $\mathrm{pH}$, daya lekat, daya sebar, dan viskositas.

a. Uji organoleptis

Pengamatan organoleptis sediaan krim meliputi pengamatan terhadap warna, tekstur, dan bau dari sediaan krim (13).

b. Pengukuran $\mathrm{pH}$

Sebanyak 1 gram krim ditimbang, lalu ditambahkan akuades yang dibuat diukur pHnya menggunakan $\mathrm{pH}$ meter. $\mathrm{pH}$ seharusnya mendekati

pH kulit yaitu 4,5 - 6,5 (13). 
c. Uji Homogenitas

Pemeriksaan homogenitas dilakukan dengan menggunakan gelas objek.

Sejumlah tertentu krim dioleskan pada kaca objek dan diamati adanya butiran kasar secara visual (13).

d. Uji Daya lekat

Sebanyak 0,5 gram krim ditimbang lalu diletakkan di atas objek gelas. Pada kedua bagian ujung objek gelas dijepit dengan penjepit, lalu diberi beban 50 gram. Dihitung lama waktu hingga objek gelas terlepas. Rentang nilai daya lekat sediaan yang baik adalah lebih dari satu detik (13).

e. Uji daya sebar

Sebanyak $0,5 \mathrm{~g}$ krim ditimbang diletakkan ditengah alat kaca penutup mulamula sudah ditimbang bobotnya, kemudiaan diletakkan diatas basis, dibiarkan 1 menit. Diameter penyebaran krim diukur setelah satu menit dengan mengambil panjang rata-rata diameter dari beberapa sisi, beban ditambahkan seberat $20 \mathrm{~g}$ kemudiaan dilakukan pengukuran kembali setelah 1 menit, dilakukan penambahan bobot tiap $20 \mathrm{~g}$. Sampai bobot yang ditambahkan kurang dari 150 dicatat diameter penyebarannya setiap penambahan bobot (13). Daya sebar diukur diameternya menggunakan jangka sorong Mitutoyo dengan ketelitian 0,01 $\mathrm{mm}$.

f. Uji viskositas

Viskositas diukur menggunakan Viskometer Brookfiled DV2T. Pengujian viskositas dilakukan dengan menyiapkan spindel pada gantungan spindel, lalu spindel diturunkan ke dalam sampel hingga tercelup, dinyalakan viskometer sambil menekan tombol, dibiarkan spindel berputar dan I ihatlah jarum merah pada skala. Angka yang tertera pada jarum menunjukkan nilai viskositas sediaan

g. Uji Sentrifugasi (13).

Sediaan krim dimasukkan dalam tabung reaksi berskala dengan ketinggian

sediaan mencapai tanda batas $10 \mathrm{~cm}$. Krim dilakukan sentrifugasi pada

kecepatan $5000 \mathrm{rpm}$ selama 30 menit. Hasil diamati apakah terjadi pemisahan fase sediaan krim yang diuji (14).

5. Penentuan Nilai Sun Protection Factor (SPF) Krim Ekstrak Daging Buah Labu Kuning

Nilai efektivitas tabir surya krim daging buah labu kuning dilakukan dengan penentuan nilai SPF pada rentang panjang gelombang $290-320 \mathrm{~nm}$ menggunakan Spektrofotometri UV-Vis (Shimadzu UV-1800®). Sediaan krim ditimbang sebanyak 0, 1 gram dan dilarutkan dalam etanol ad $10 \mathrm{~mL}$ etanol $96 \%$ pro analisis. Hasil absorbansi dilakukan perhitungan nilai SPF sebagai berikut $(1,6){ }_{S P F}=C F x \sum_{290}^{320} E E(\lambda) x I(\lambda) x$ absorbansi $(\lambda)$ 
Keterangan :

$\mathrm{CF} \quad=$ faktor korelasi (10)

$\mathrm{EE} \quad=$ eritemal effect spectrum

I = spektrum simulasi sinar surya

$\lambda=$ absorbansi produk tabir surya

Tabel 2 Konstanta EE dan I Perhitungan SPF (7)

\begin{tabular}{cc}
\hline Panjang gelombang (nm) & EE x I \\
\hline 290 & 0,0150 \\
295 & 0,0817 \\
300 & 0,2874 \\
305 & 0,3278 \\
310 & 0,1864 \\
315 & 0,0839 \\
320 & 0,0180 \\
\hline
\end{tabular}

\section{Hasil}

Sediaan krim yang dibuat dilakukan pengamatan karakteristik fisik krim meliputi uji organoleptis, $\mathrm{pH}$, homogenitas, daya lekat, daya sebar, viskositas serta uji sentrifugasi. Penentuan efektivitas sebagai tabir surya dilakukan dengan penentuan nilai SPF.

Tabel 3 Karakteristik fisik krim ekstrak daging labu kuning penyimpanan suhu $28 \pm 2{ }^{\circ} \mathrm{C}$

\begin{tabular}{|c|c|c|c|c|c|c|c|c|c|c|c|c|}
\hline \multirow{3}{*}{ 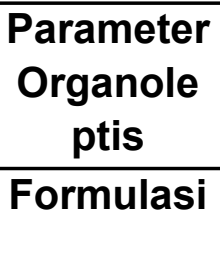 } & \multicolumn{12}{|c|}{ Lama Penyimpanan (Hari) } \\
\hline & \multicolumn{4}{|c|}{ Hari 0} & \multicolumn{4}{|c|}{ Hari ke 7} & \multicolumn{4}{|c|}{ Hari ke 14} \\
\hline & $\begin{array}{l}\text { Bas } \\
\text { is }\end{array}$ & $\overline{F 1}$ & F2 & F3 & $\begin{array}{c}\text { Bas } \\
\text { is }\end{array}$ & F1 & F2 & F3 & $\begin{array}{c}\text { Bas } \\
\text { is }\end{array}$ & F1 & F2 & F3 \\
\hline Warna & $P$ & $\mathrm{KM}$ & $\mathrm{KM}$ & $\bar{K}$ & $P$ & $\mathrm{KM}$ & KM & $\mathrm{K}$ & $P$ & KM & $\mathrm{KM}$ & $\mathrm{K}$ \\
\hline Tekstur & SP & SP & SP & SP & SP & SP & SP & SP & SP & SP & SP & SP \\
\hline Bau & BK & BK & BM & BM & BK & BK & BM & BM & BK & BK & BM & BM \\
\hline $\begin{array}{c}\text { Homogenit } \\
\text { as }\end{array}$ & $\mathrm{H}$ & $\mathrm{H}$ & $\mathrm{H}$ & $\mathrm{H}$ & $\mathrm{H}$ & $\mathrm{H}$ & $\mathrm{H}$ & $\mathrm{H}$ & $\mathrm{H}$ & $\mathrm{H}$ & $\mathrm{H}$ & $\mathrm{H}$ \\
\hline $\mathrm{pH}$ & 6,0 & 6,0 & 5,4 & 5,3 & 6,06 & 6,0 & 5,4 & 5,3 & 6,11 & 6,0 & 5,4 & 5,3 \\
\hline & 6 & 3 & 6 & 2 & $\pm 0,0$ & 5 & 6 & 3 & $\pm 0,0$ & 5 & 5 & 5 \\
\hline & $\begin{array}{c} \pm 0,0 \\
0\end{array}$ & $\begin{array}{l} \pm 0 \\
47\end{array}$ & $\begin{array}{l} \pm 0 \\
00\end{array}$ & $\begin{array}{l} \pm 0, \\
01\end{array}$ & 0 & $\begin{array}{l} \pm 0 \\
48\end{array}$ & $\begin{array}{l} \pm 0 \\
01\end{array}$ & $\begin{array}{l} \pm 0 \\
01\end{array}$ & 0 & $\begin{array}{l} \pm 0 \\
48\end{array}$ & $\begin{array}{l} \pm 0 \\
01\end{array}$ & $\begin{array}{l} \pm 0, \\
00\end{array}$ \\
\hline
\end{tabular}

$\mathrm{P}$ : putih; KM : kuning muda; $\mathrm{K}$ : kuning; SP : semi padat; $\mathrm{BK}$ : bau minyak kelapa; $\mathrm{BM}$ : bau manis; $\mathrm{H}$ : homogen 

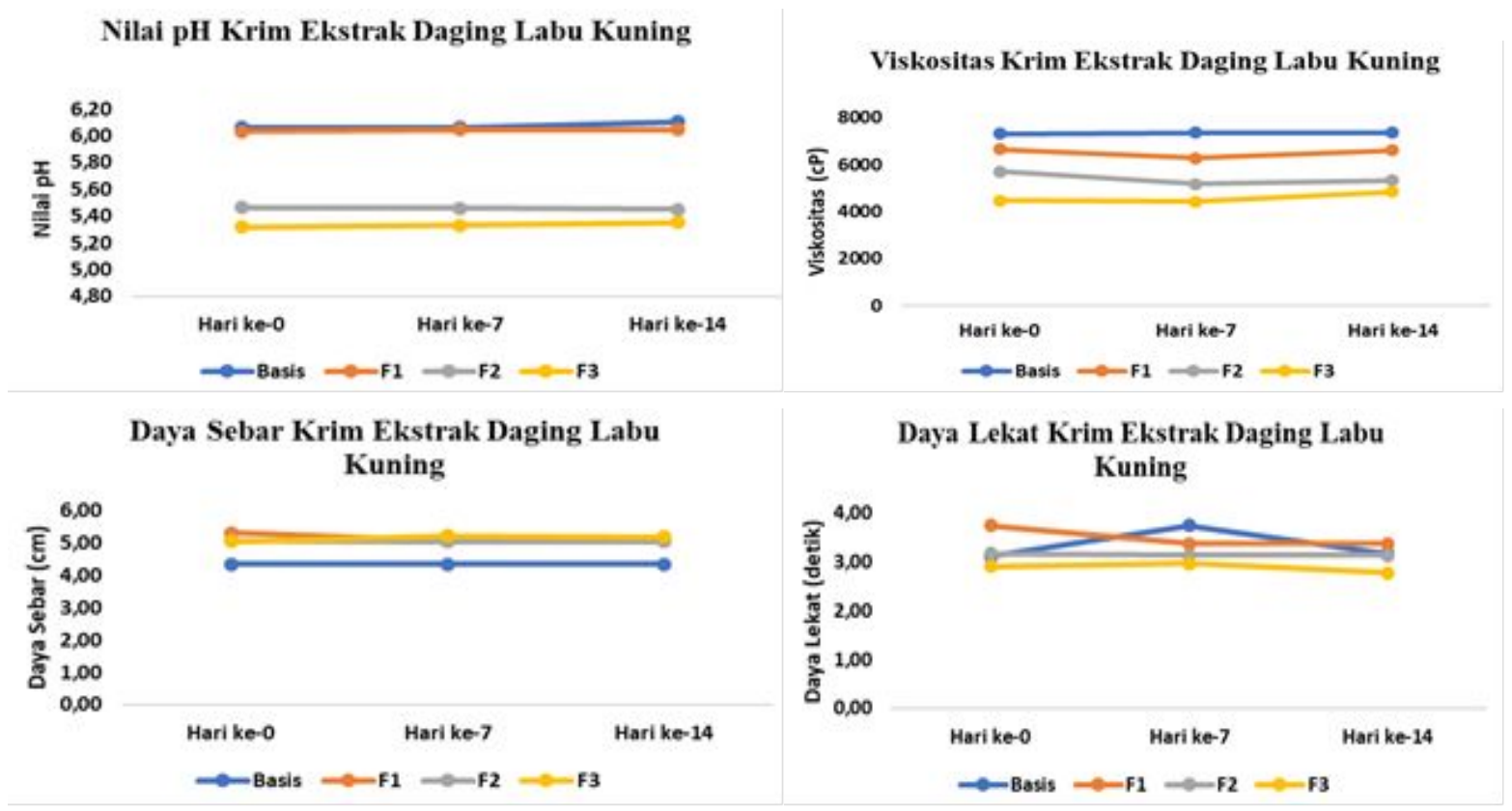

Gambar 2 Karakteristik fisik pH, viskositas, daya sebar, dan daya lekat krim ekstrak daging buah labu kuning pada penyimpanan selama 14 hari

Tabel 4 Hasil Uji Sentrifugasi Krim Ekstrak Daging Labu Kuning

\begin{tabular}{cc}
\hline Sediaan & Uji Sentrifugasi \\
\hline Basis & Tidak terjadi pemisahan \\
F1 & Tidak terjadi pemisahan \\
F2 & Tidak terjadi pemisahan \\
F3 & Tidak terjadi pemisahan \\
\hline
\end{tabular}

Tabel 5 Nilai SPF Krim Ekstrak Daging Labu Kuning

\begin{tabular}{cc}
\hline Sediaan & Nilai SPF Krim \\
\hline Basis & $0,45 \pm 0,00$ \\
F1 & $2,15 \pm 0,01$ \\
F2 & $4,69 \pm 0,04$ \\
F3 & $5,78 \pm 0,02$ \\
\hline
\end{tabular}

\section{Pembahasan}

Hasil pengamatan organoleptis krim selama penyimpanan 14 hari menunjukkan tidak adanya perubahan pada warna, tekstur dan bau yang terlihat pada tabel 3 . Krim ekstrak daging labu kuning memiliki warna kuning, berbentuk semi padat dan berbau manis. Semakin besar konsentrasi ekstrak daging labu kuning yang ditambahkan akan menghasilkan sediaan yang berwarna lebih kuning pekat. 
Hal ini dipengaruhi oleh warna ekstrak labu kuning yang menghasilkan sediaan berwarna kuning dengan intensitas warna tergantung pada perlakuan pengeringan serta jenis labu kuning $(15,16)$. Sediaan krim pada semua formulasi menunjukkan sediaan yang homogen. Krim yang homogen ditandai dengan tidak adanya butiran kasar pada gelas objek. Pengujian homogenitas dilakukan untuk melihat apakah terjadi ketidakcampuran bahan basis dengan tambahan bahan yang lain pada proses pembuatan. Sediaan krim harus memenuhi syarat homogen sehingga terdistribusi merata saat diaplikasikan pada permukaan kulit serta mudah digunakan (17).

Krim daging labu kuning menunjukkan nilai $\mathrm{pH}$ berkisar antara 5,32 $-6,11$. Nilai $\mathrm{pH}$ pada basis lebih tinggi dibandingkan $\mathrm{pH}$ krim yang mengandung ekstrak daging labu kuning. Penurunan $\mathrm{pH}$ disebabkan karena ekstrak mengandung senyawa yang bersifat asam seperti vitamin $\mathrm{C}$. Daging buah labu kuning mengandung vitamin $\mathrm{C}$ yang tinggi yaitu sebesar $14,18 \mathrm{mg} / 100 \mathrm{~g}(18)$. Semakin besar konsentrasi ekstrak menunjukkan nilai $\mathrm{pH}$ krim semakin asam ditunjukkan oleh nilai $\mathrm{pH}$ yang lebih rendah terlihat pada tabel 3. Krim daging buah labu kuning telah sesuai dengan $\mathrm{pH}$ kulit manusia yang berkisar antara $4-7$ (19). Krim daging labu kuning pada penyimpanan selama 14 hari tidak menunjukkan adanya perubahan yang signifikan $(p>0,05)$ menggunakan analisis paired sample T test.

Daya sebar krim daging buah labu kuning berkisar antara 5,04 - 5,31 sedangkan pada basis menunjukkan nilai daya sebar sebesar $4,33 \pm 0,08$. Uji daya sebar digunakan untuk mengetahui kemampuan krim menyebar serta menentukan mudah tidaknya untuk diaplikasikan pada kulit (14). Daya sebar krim basis yang rendah dipengaruhi oleh kandungan cera alba yang berfungsi sebagai stiffening agent yang dapat meningkatkan konsistensi sediaan krim (20). Daya sebar yang rendah dipengaruhi oleh penggunaan cera alba pada konsenstrasi yang tinggi. Daya sebar krim yang mengandung ekstrak daging labu kuning menunjukkan daya sebar yang lebih besar, hal ini dipengaruhi oleh penambahan ekstrak yang memiliki konsistensi encer sehingga menghasilkan krim dengan daya penyebaran yang lebih besar. Daya sebar krim daging labu kuning pada penyimpanan selama 14 hari tidak menunjukkan perubahan yang signifikan $(p>0,05)$.

Daya lekat basis dan krim daging labu kuning berkisar antara 2,77 - 3,73 detik. Daya lekat menunjukkan kemampuan sediaan dalam melapisi kulit secara kedap, tidak menyumbat pori - pori serta tidak mempengaruhi fungsi fisiologis kulit (21). Kemampuan daya lekat dilakukan dengan melihat lamanya waktu basis sediaan melekat pada kulit. Semakin tinggi nilai daya lekat maka semakin lama kontak krim dengan kulit sehingga zat aktif yang terdapat dalam sediaan diharapkan akan lebih banyak yang diabsorpsi (22). Hasil pengujian daya lekat menunjukkan hasil yang berbanding terbalik dengan nilai daya sebar. Semakin besar konsentrasi ekstrak akan dihasilkan sediaan yang memiliki daya sebar semakin besar sedangkan daya lekat semakin kecil. Nilai daya sebar yang tinggi menunjukkan kemampuan penyebaran krim yang tinggi tetapi melekat lebih cepat pada kulit. Berdasarkan analisis statistik penyimpanan krim selama 14 hari tidak menunjukkan perubahan nilai daya lekat yang signifikan $(p>0,05)$. 
Viskositas merupakan sifat fisik sediaan yang akan mempengaruhi kecepatan flokulasi (23). Viskositas menunjukkan tahanan sediaan untuk mengalir dimana semakin tinggi viskositas maka tahanan mengalir semakin tinggi (21). Viskositas krim berkisar antara 4480 - 7360 cP. Basis memiliki viskositas yang paling besar dibandingkan krim yang mengandung ekstrak daging labu kuning. Krim yang mengandung konsentrasi ekstrak paling besar menunjukkan nilai viskositas yang semakin rendah, hal ini dipengaruhi oleh karakteristik ekstrak berupa cairan kental sehingga akan menghasilkan sediaan yang semakin encer. Nilai viskositas krim telah memenuhi persyaratan sediaan tabir surya yang dipersyaratkan yaitu sebesar 2000 - 50.000 cP (6). Viskositas krim dipengaruhi oleh komposisi cera alba serta bahan lain yang dapat mempengaruhi viskositas seperti propilen glikol dan VCO yang konsistensinya cair (24). Penyimpanan selama 14 hari tidak menunjukkan perubahan nilai viskositas pada sediaan basis dan krim daging labu kuning $(p>0,05)$.

Berdasarkan uji stabilitas dengan metode sentrifugasi sediaan krim stabil ditandai dengan tidak adanya pemisahan fase dan terlihat krim tetap homogen setelah dilakukan uji mekanik pada kecepatan 5000 rpm selama 30 menit. Uji sentrifugasi dapat melihat efek guncangan pada jalur transportasi sediaan terhadap tampilan fisik produk (6). Uji stabilitas sediaan penting dilakukan untuk mempredikasikan kondisi krim ketika dilakukan penyimpanan.

Pengujian aktivitas tabir surya basis dan krim daging labu kuning dilakukan menggunakan metode Spektrofotometri UV $(1,25)$. Penentuan aktivitas tabir surya dilakukan dengan pengukuran absorbansi pada panjang gelombang $290-320 \mathrm{~nm}$ untuk mendapatkan nilai SPF. Formulasi basis krim tidak menunjukkan adanya aktivitas tabir surya. Krim F1 memiliki nilai SPF 2,15 $\pm 0,01$ termasuk kategori proteksi minimal, F2 dan F3 memiliki nilai SPF 4,69 $\pm 0,04$ dan 5,78 $\pm 0,02$ termasuk dalam kategori proteksi sedang yang dapat dilihat pada Tabel 5 (26). Aktivitas tabir surya diduga dipengaruhi oleh kandungan metabolit sekunder yang terkandung dalam ekstrak daging labu kuning seperti polifenol, tokoferol dan karotenoid. Polifenol memiliki kemampuan proteksi melalui mekanisme pada ikatan rangkap terkonjugasi sehingga dapat menghambat absorbsi sinar matahari, Adanya kandungan karotenoid dan tokoferol dapat meningkatkan aktivitas tabir surya yang sering ditambahkan dalam kosmetik tabir surya. Tokoferol merupakan antioksidan larut lemak yang berperan dalam melindungi membrane sel dari peroksidasi lemak akibat paparan radikal bebas. Tokoferol mampu meningkatkan hidrasi stratum korneum, meningkatkan pengikatan air pada kulit, mampu menembus lapisan kulit terdalam serta dapat berperan sebagai antioksidan pada epidermis kulit. Kandungan polifenol seperti flavonoid selain berfungsi sebagai antioksidan juga berperan menurunkan paparan sinar UV $(25,27)$.

\section{Kesimpulan}

Krim yang mengandung ekstrak daging labu kuning memiliki aktivitas tabir surya dengan kategori proteksi sedang pada konsentrasi ekstrak 5\% dan 10\%. Formulasi krim daging buah labu kuning memenuhi parameter sifat fisik dan stabil pada penyimpanan suhu ruang selama 14 hari pada parameter organoleptis, $\mathrm{pH}$, daya sebar, daya lekat, viskositas dan uji sentrifugasi. 


\section{Ucapan Terima Kasih}

LPPM (Lembaga Penelitian dan Pengabdian kepada Masyarakat) Universitas Ngudi Waluyo atas Hibah Dana Penelitian Internal dengan nomor kontrak 002/KTR-PENELITIAN /LPPM/UNW/VI/2021.

\section{Deklarasi Konflik Kepentingan}

Semua penulis menyatakan tidak ada konflik kepentingan dalam penulisan naskah publikasi ini.

\section{Daftar Pustaka}

1. Rasheed A, Shama SN, Mohanalakshmi S, Ravichandran V. Formulation, characterization and in vitro evaluation of herbal sunscreen lotion. Orient Pharm Exp Med. 2012;12(4):241-6.

2. He hailun, $\mathrm{Li}$ anqi, $\mathrm{Li}$ shiqin, Tang jie, Li li, Xiong lidan. Natural components

in sunscreens: Topical formulations with sun protection factor (SPF).

Biomed Pharmacother. 2021;134(October 2020).

3. Berkey C, Oguchi N, Miyazawa K, Dauskardt R. Role of sunscreen $f$ ormulation and photostability to protect the biomechanical barrier function of skin.

Biochem Biophys Reports [Internet]. 2019;19(June):100657. Available from: https://doi.org/10.1016/j.bbrep.2019.100657

4. Geoffrey K, Mwangi AN, Maru SM. Sunscreen products: Rationale for use, formulation development and regulatory considerations. Saudi Pharm J [Internet]. 2019;27(7):1009-18. Available from: https://doi.org/10.1016/j.jsps.2019.08.003

5. Yamada M, Mohammed Y, Prow TW. Advances and controversies in studying sunscreen delivery and toxicity. Adv Drug Deliv Rev [Internet]. 2020;153:72-86. Available from: https://doi.org/10.1016/j.addr.2020.02.001

6. Putri YD, Kartamihardja H, Lisna I. Formulasi dan Evaluasi Losion Tabir Surya

Ekstrak Daun Stevia (Stevia rebaudiana Bertoni M). J Sains Farm Klin. 2019;6(1):32-6.

7. Lailiyah M, Saputra SA, Sari F. Antioxidant activity and sun protection factor evaluation for cream formulation of purified roasted corn silk extracts (Zea Mays

L. Saccharata). Pharmaciana. 2020;10(3):371.

8. Rajasree RS, Sibi PI, Francis F, William H. Phytochemicals of cucurbitaceae family - A review. Int J Pharmacogn Phytochem Res. 2016;8(1):113-23.

9. Kim MY, Kim EJ, Kim YN, Choi C, Lee BH. Comparison of the chemical compositions and nutritive values of various pumpkin (Cucurbitaceae) species and parts. Nutr Res Pract. 2012;6(1):21-7.

10. Sunnah I, Erwiyani AR, Melati N, Yunisa O. Efektivitas Komposisi Polivynil Alkohol, Propilenglikol dan Karbomer Terhadap Optimasi Masker Gel Peel-off Nano Ekstrak Daging Buah Labu Kuning (Cucurbita maxima D). JPSCR. 2019;4(2):82-94. 
11. Sheskey PJ, Cook WG, Cable CG, American Pharmacists Association. Handbook of pharmaceutical excipients. 8th Revised. Pharmaceutical Press; $1184 \mathrm{p}$.

12. Chasanah U. Uji Aktivitas Antioksidan Krim Ekstrak Green Tea dengan

Fase

Minyak VCO dan Minyak Zaitun dengan Metode DPPH. Senas Pro 2.

2017;(188):137-41.

13. Erwiyani AR, Luhurningtyas FP, Sunnah I. Optimasi Formula Sediaan

Krim

Ekstrak Etanol Daun Alpukat (Persea Americana Mill ) dan Daun Sirih Hijau (Piper Betle Linn). Cendekia J Pharm. 2017;1(1).

14. Pratasik MCM, Yamlean PVY, Wiyono WI. Formulasi Dan Uji Stabilitas Fisik

Sediaan Krim Ekstrak Etanol Daun Sesewanua (Clerodendron Squamatum Vahl.). Pharmacon. 2019;8(2):261-7.

15. Indrianingsih AW, Rosyida VT, Apriyana W, Nur Hayati S, Nisa K, Darsih C, et al. Comparisons of antioxidant activities of two varieties of pumpkin (Cucurbita moschata and Cucurbita maxima) extracts. IOP Conf Ser Earth Environ Sci. 2019;251(1).

16. Indrianingsih AW, Apriyana W, Rosyida VT, Nisa K, Nurhayati S, Darsih C. Efek

Pengeringan pada Bagian Buah Labu Kuning (Cucurbita Moschata) terhadap Aktivitas Antioksidan, Sifat Kimia dan Struktur Morfologi. J Ris Teknol Ind. 2019;13(1):33.

17. Meila O, Pontoan J, Uun HW, Pratiwi A. Formulasi Krim Ekstrak Etanol Daun Beluntas (Pluchea indica L.,) dan Uji Kestabilan Fisiknya. Indones Nat Res Pharm J. 2017;1(2):95-106.

18. Mittal S, Dhiman AK, Sharma A, Attri S, Kathuria D. Standardization of Recipes 19. Lambers H, Piessens S, Bloem A, Pronk H, Finkel P. Natural skin surface $\mathrm{pH}$ is on average below 5 , which is beneficial for its resident flora. Int $\mathrm{J}$ Cosmet Sci. 2006;28(5):359-70.

19. Lambers H, Piessens S, Bloem A, Pronk H, Finkel P. Natural skin surface pH is on average below 5 , which is beneficial for its resident flora. Int $\mathrm{J}$ Cosmet Sci. 2006;28(5):359-70

20. Rowe RC, Sheskey PJ, Quinn ME. Handbook of Pharmaceutical Excipients. Sixth Edit. Quinn ME, editor. London: Pharmaceutical Press; 2009.

21. Ermawati DE, Yugatama A, Wulandari W. Uji Sifat Fisik, Sun Protecting Factor, dan In Vivo ZnO Terdispersi dalam Sediaan Nanoemulgel. JPSCR J Pharm Sci Clin Res. 2020;5(1):49.

22. Forestryana, Dyera., Yuliani., Putri, aristha N. Optimasi Sediaan Krim Ekstrak Etanol 95\% Daun Pandan Wangi (Pandanus amaryllifolius Roxb.). Borneo J Phamascientech. 2010;04(01):22-31.

23. Kartini K, Winarjo BM, Fitriani EW, Islamie R. Formulation and pH- Physical

Stability Evaluation of Gel and Cream of Plantago major Leaves Extract. Media Pharm Indones. 2017;1(3):174-80.

24. Sayuti NA. Formulasi dan Uji Stabilitas Fisik Sediaan Gel Ekstrak Daun Ketepeng Cina (Cassia alata L.). J Kefarmasian Indones. 2015;5(2):74-82. 
25. Eff ARY, Rahayu ST, Saraswati H, Mun'im A. Formulation and Evaluation of Sunscreen Gels Containing Mangiferin Isolated from Phaleria macrocarpa Fruits. Int J Pharm Investig. 2019;9(3):141-5.

26. Lestari I, Prajuwita M, Lastri A. Penentuan Nilai SPF Kombinasi Ekstrak D aun Ketepeng dan Binahong Secara In Vitro. Parapemikir J Ilm Farm [Internet]. 2021;10(1):1-10. Available from:

http://www.ejournal.poltektegal.ac.id/index.php/parapemikir/article/view/2030 27. Nada AH, Zaghloul AA, Hedaya MA, Khattab IS. Stability of Vitamin E dan Vitamin E Acetate Containing Cosmetic Preparations. J Glob Pharma Technol. 2012;4(03):1- 